\title{
Bor Mineralinin Tekstil Sanayiinde Kullanımı ve Türkiye Ekonomisine Katkısı ${ }^{1}$
}

\author{
The Use of Boron Mineral in the Textile Industry and Its Contribution to the \\ Turkish Economy \\ İsa DAL ${ }^{2 a}$ \\ Şöhret Aktepe DAL ${ }^{3}$
}

\author{
${ }^{2}$ Haliç Üniversitesi, dalisa@isadal.com Orcid ID: 0000-0002-1430-4916 \\ 3 Pamukkale Üniversitesi, sohretaktepe@hotmail.com Orcid ID: 0000-0002-3542-7034 \\ aYazışlan yazar/Corresponding author
}

$\begin{array}{ll}\text { Article Info: } & \text { Research Article } \\ \text { Date Submitted: } & 12.07 .2021 \\ \text { Date Revised: } & 12.08 .2021 \\ \text { Date Accepted: } & 17.08 .2021\end{array}$

Abstract

Although our country has approximately 73\% of the world's reserves, Turkey exports its boron as a raw mineral, which is sold at cheap prices and reduces the required profit from the boron market by half. In order to increase the profit share of Turkey in the boron market, it is necessary to turn to processed boron products with much higher added value, to increase their production capacity, to increase their usage areas and product diversity. With a significant share in the export of our country, the usage of boron in the textile industry is very limited. Boron is used in limited areas other than certain industrial branches in our country. It is necessary to encourage the use of the boron in potential sectors such as the textile industry, to involve university-industry cooperation, and to seek new technology and production through RED activities. In this article, the properties, usage areas, and place of boron in the world boron market were examined, where our country has 3/2 boron reserves in the world and it is considered to be a kind of national treasure. In this research, applications of boron-doped nanocomposite material were conducted in a laboratory environment onto a $100 \%$ cotton fabric.

Keywords: Boron, Textile, Fashion, RED (Research and Development), Production, Design, Industry.

JEL codes: I11, I15, L23.

$\begin{array}{ll}\text { Makale Bilgisi: } & \text { Araştırma Makalesi } \\ \text { Geliş Tarihi: } & 12.07 .2021 \\ \text { DüzeltmeTarihi: } & 12.08 .2021 \\ \text { Kabul Tarihi: } & 17.08 .2021\end{array}$

Özet

Ülkemiz dünya bor rezervlerinin yaklaşık olarak \%73 'üne sahip olmasına karşın, Türkiye bor ihracatını ucuz fiyata satılan ham bor olarak gerçekleştirmekte ve bor pazarından elde etmesi gereken kârı yarı yarıya düşürmektedir. Türkiye'nin bor pazarındaki kâr payını yükseltmek için, katma değeri çok daha yüksek olan işlenmiş bor ürünlerine yönelmek, üretim kapasitelerini, kullanım alanları ve ürün çeşitliliğini artırmak gerekmektedir. Ancak, ülkemizde halen belli başlı sanayi kolları dışında sınırlı alanlarda kullanılan bor cevheri, ülkemiz ihracatında çok önemli bir paya sahip tekstil sanayi alanındaki çalışmalar çok kısıtlıdır. Bor piyasasının tekstil sanayi gibi potansiyel sektörlerde kullanımını teşvik etmek, Üniversite-sanayi iş birliğine girerek AR-GE faaliyetleri ile yeni teknoloji ve üretim arayışlarına girmek gerekmektedir. Buradan hareketle bu çalışmada, dünyanın 3/2 si gibi bir oranda bor rezervlerine sahip olan ülkemizde bir nevi milli hazinemiz sayılan bor madeninin özellikleri, kullanım alanları ve dünya bor pazarındaki yeri incelenmiş; laboratuvar ortamında yapılan örnek bir araştırma ve uygulama ile bor katkul Nanokompozit malzeme \%100 pamuklu kumaşa uygulanmış ve elde edilen veriler paylaşılmıştır.

Anahtar Kelimeler: Bor, Tekstil, Moda, AR-GE (Araştırma- Geliştirme), Üretim, Tasarım, Sanayi.

JEL kodları: I11, I15, L23.

\footnotetext{
${ }^{1}$ Yazarlar bu çalışmanın tüm süreçlerinin araştırma ve yayın etiğine uygun olduğunu, etik kurallara ve bilimsel atıf gösterme ilkelerine uyduğunu beyan etmişlerdir. Aksi bir durumda Pamukkale Journal of Eurasian Socioeconomic Studies Dergisi sorumlu değildir. İntihal raporu alınmıştır. / The authors declared that all processes of this study comply with research and publication ethics, and comply with ethical rules and scientific citation principles. Otherwise, Pamukkale Journal of Eurasian Socioeconomic Studies is not responsible. A plagiarism report is received.
} 


\section{EXTENDED SUMMARY}

Research Problem: In the study, it was aimed to expand the natural properties of boron mine, which is one of the most important natural treasures of our country, and its application areas in textile and fashion design, both on an academic and sectoral basis, through an exemplary research and application. The possibilities that research and study and usage opportunities will provide to the economy have also been evaluated.

Research Questions: What are the properties of boron mineral?

In which regions is the boron mineral located in Turkey?

Can studies be carried out for the textile and apparel industry with boron mineral?

Literature Review: The literature review of the study consists of master's and doctoral theses, national and international sources such as books and articles, as well as reports in the archives of government institutions.

Methodology: In the study, the scanning method, one of the qualitative research methods, was used within the framework of the field of Social Sciences. This method was also supported by the product designs made by the author for the field of textile and ready-made clothing.

Result and Conclusion: The fact that boron is used as a substitute for each other in the main industry branches in our country, the product diversity has not been increased and it has not been evaluated in some industry branches yet or remains very limited is undoubtedly due to the lack of R\&D studies that need to be done with the university, industry and universityindustry cooperation. While it has such an important role in terms of boron reserves in the world, the fact that our country has one of the least academic publications on boron supports this situation. Our country should move away from the negativity of exporting raw boron and implement projects aimed at exporting processed boron with high added value. Boron Research and Product Development Centers should be opened in our country and importance should be given to the use of boron mine in the production of many industrial areas. Especially in the textile industry, where we have an important share in the production and export of products in the world market, considering our boron reserve and our advantages in textile exports, increasing our awareness level about boron and putting it into circulation will make numerous contributions to our country economically.

By applying the nanocomposite material to the $100 \%$ cotton product with various technical and chemical processes; Boron-added new cotton fabrics, which have gained many technical features such as Anti-Bacterial, UPF 50+ Ultraviolet Protection, Electromagnetic Shielding, Radon Gas Absorption, Late Flammability, Increased Strength, Superior Water AbsorptionHydrophility, Non-Formaldehyde, have been transformed into various textile products in the images below. . In the study, it is hoped that the product designs made from boron added cotton products will set an example and shed light on new studies. 


\section{GİRİ̧̧}

Bor, kimya sanayinden, ilaç sanayine, nükleer sanayiden otomobil sanayine, endüstrinin tarım, cam, sağlık, deterjan, enerji sistemleri gibi 400 'den fazla alanda kullanılmakta ve gereksinimi gün geçtikçe artarak kullanım alanları sürekli genişletilmektedir. Ülkelerin ekonomik olarak güçlenmesi ve gelişmesinde, sanayi kollarını ve üretim sektörlerini doğrudan besleyen madenler, son derece önemli bir role sahiptir. Coğrafi olarak stratejik bir konumda bulunan Türkiye madenler açısından da zengin ve elverişli topraklara sahiptir. Bu madenler arasında, günümüzde dünyanın en önemli madenleri arasında ilk sıralarda yer alan bor madeninin de dünya rezervinin yaklaşık olarak \%73'üne ev sahipliği yapmaktadır.

Türkiye'deki bor yatakları özellikle Kırka/Eskişehir, Bigadiç/Balıkesir, Kestelek/Bursa ve Emet/Kütahya'da bulunmaktadır. Dünya' daki bor rezervlerinin önemli miktarına sahip olan Türkiye'de rezerv açısından en çok bulunan bor cevherleri Tinkal (Na2O.2B2O3.10H2O) ve kolemanit (2CaO.3B2O3.5H2O) tir. Dırak'a göre (2011), Türkiye'deki önemli Tinkal yatakları Kırka 'da bulunurken kolemanit yatakları Emet ve Bigadiç civarındadır. Ek olarak, Bigadiç'te düşük miktarda Üleksit rezervi bulunur. Kestelek'te zaman zaman Üleksit yan ürün olarak elde edilir.

Bor'un saf elementi; ilk kez 1808 yılında Fransız kimyager J. L. Gay - Lussac ve Baron L.J. Thenard ile İngiliz kimyager H. Davy tarafindan elde edilmiştir (Anon., 2018; Karakaş, 2008). Anadolu'da ise bor yataklarının bulunuşu ve işletilmesi Romalılar devrine uzanmaktadır. 13 ve 14. yüzyıllarda Susurluk ilçesinin Sultançayır mevkiindeki Pandermit yataklarının Romalılar tarafından işletildiği düşünülmektedir. Ancak yıllar boyunca Türkiye'deki bor madenleri, muhtelif yerli ve yabancı şirketler tarafından vergi ödemeden yurtdışına çıkarılmış veya işletilmiştir (TMMOB, 2016).

Bor, oksijenle bağ kurmaya yatkın olduğu için çok sayıda değişik oksijen bileşiği meydana getirir. Bu mineraller yapılarında farklı oranlarda bor oksit içeren bileşiklerdir. Ticari olarak en önemli bor mineralleri; Tinkal, Kolemanit, Kernit, Üleksit, Pandermit, Borasit, Szaybelit ve Hidroborasit'tir. Uluslararası kalite standartlarında yüksek katma değerli ürünlere dönüştürülen başlıca bor mineralleri ise; Tinkal, Kolemanit ve Üleksit'tir. Bor elementi, Eti Maden tarafından çeşitli yöntemlerle fiziksel işlemler uygulanarak zenginleştirilir ve konsantre bor ürünlerine dönüşür. Daha sonra tesislerde rafine edilerek yüksek verimli, karlı ve sürdürülebilir bor ürünlerine dönüştürülerek cam, seramik, tarım, deterjan ve temizlik sektörleri başta olmak üzere endüstrinin birçok alanında kullanılmaktadır (Anon, 2018; Yenmez, 2009).

Günümüzde gelişen sanayi ve teknolojik ilerlemelerle cam sanayi, deterjan sanayi, metalürji, tarım ve nükleer uygulamalar gibi pek çok alanda temel girdi maddelerin başında gelen bor mineralleri canlıların da yaşantısını devam ettirmesi için vazgeçilmez mineral kaynaklarından biridir. Dünyadaki bor rezervlerinin çoğu Türkiye' dedir. Dünyada B2O3 bazında toplam 1,176 milyon ton olan bor rezervlerinde Türkiye'nin payı \%72,3, ABD'nin payı \%6,8 ve Rusya'nın pay1 \%8,5'tir (Yenmez, 2009).

Ülkemizin, Dünya'nın sayılı büyük bor rezervlerine sahip ülkelerinden biri olması (yaklaşık olarak 3/2), bu yönü ile bor madeninin ülkemizin milli hazine kaynaklarının en önemlilerinden biri olmasına rağmen, belli başlı sanayilerin haricinde kısıtlı şekilde kullanımı, ve endüstride, 
ülkemizin önemli sanayi kollarından biri olan tekstil sektöründe yeteri kadar tanınmaması ve sayısız olanaklarından faydalanılmaması çalışmanın itici gücü olmuştur.

Buna göre; genelde, borun tanımı, tarihçesi, teknik özellikleri ve kullanım alanları paylaşılmış, özelde laboratuvar ortamında bor madeninin kullanıldığ 1 tekstil ürünlerinde doğallık ve performans arayan kullanıcı ve profesyonellere; UV ışınından koruma, anti bakteriyel olmasıyla hijyenik olma, homojen yüzeye sahip olmasıyla hızlı emicilik ve hızlı kuruma, nötron tutma ve doğallık niteliklerini sunan bor temelli kumaş teknolojisi olanakları araştırılmıştır.

Ülkemizde tekstil sektöründe bor madeninin uygulama ve kullanımının arttırılmasına katkı sağlaması amacı yapılan çalışmada; \%100 pamuklu ürünlere bor mineralinin özgün tekniklerle birleştirilmesi hedeflenerek; bor mineralinin tekstil lif ve yüzeyine sağlayacağ 1 özellikler ile farklı kumaş tiplerinin ortaya çıkartılması, bu kumaşların günümüzde rahatlıkla kullanılabilecek ergonomi ve rahatlık içerecek şekilde tasarıma dönüştürülmesi üzerine araştırma ve uygulamalar yapılmıştır. Nanokompozit malzemenin çeşitli teknik ve kimyasal işlemlerle \%100 pamuklu ürüne tatbik edildiği araştırmada, pamuklu ürünün kazandığı bir çok teknik özelliğe çalışmanın bulgular bölümünde, bor katkılı yeni pamuklu kumaşlardan tasarlanan çeşitli tekstil ürünlerine uygulamalar bölümünde yer verilmiştir.

\section{BORUN TARİHÇESİ, GENEL ÖZELLIKKLERI VE KULLANIM ALANLARI}

\subsection{Borun Tarihçesi}

Bor, kelime kökeni olarak Arapça, "Burag/Baurach" ve Farsça' da "Burah" kelimelerinden türemiş, kimyasal bir elementtir. Tarihte ilk olarak M.Ö. Babillerin kullandığı bor madeni, Mısırlılar, Yunan ve Romalılar tarafından, altın işletmeciliği, mumyalama, metal oymacılığı, temizlik ve tedavi amaçlı kullanılmıştır. (Hildebrand, 1982).

Bor bileşikleri binlerce yıldır bilinmesine rağmen elementer borun keşfi 1808 yılında Sir Humphry ve Gay Lussac tarafından keşfedilmiştir. Tarihte ilk olarak 4000 yıl önce Babiller Uzak doğudan borak ithal etmiş ve bunu altın işletmeciliğinde de kullanmışlardır. Mısırlarında boru, mumyalamada, tıpta ve metalürji uygulamalarında kullandıkları bilinmektedir. İlk boraks kaynağı Tibet göllerinden elde edilmiştir. Eski Yunanlılar ve Romalılar ise boratları temizlik maddesi olarak kullanmıştır.

İlaç olarak ilk olarak Arap doktorlar tarafından M.S. 875 yılında kullanılmıştır. 1772 yılında İtalya'nın Scany bölgesindeki sıcak su kaynaklarında doğal olarak borik asit "Sasolit" minerali keşfedilmiştir. 1836 yılında ise Şili ve Arjantin'deki boratlar bulunmuş ve bu yataklar 19 . yüzyılın sonlarına kadar dünyada bor elde edilen en büyük kaynaklar haline gelmiştir. 1864 yılında da Amerika'nın Kaliforniya ve Navada eyaletlerindeki bor yatakları keşfedilmiştir. (Bilgiç, M., Dayık, M. Teknolojik Araştırmalar: TTED 2013 (2) 27-37 29 2.2.)

\subsection{Borun Genel Özellikleri}

Bor (B), yerkabuğunun \%0.001 'ini oluşturur. Doğada serbest olarak bulunmayan B' un, kütle numarası LO ve II olan kararlı iki izotopu vardır. Özgül ağırlığ $2.84 \mathrm{~g} / \mathrm{cm} 3$, atom ağırlığ 10.82 ve ergime noktasi $2300^{\circ} \mathrm{C}$ 'dir. Su ile $100^{\circ} \mathrm{C}^{\prime} \mathrm{de}$, oksijenle $700^{\circ} \mathrm{C}$ 'de, hidrojenle $840^{\circ} \mathrm{C}$ 'de reaksiyona girmektedir. Yüksek sıcaklıkta su ile reaksiyonu sonucunda borik asit ve diğer bor bileşenlerine dönüşür (Karagölge vd., 2002) 
Doğada hiçbir zaman serbest halde bulunmayan bor elementi, çeşitli metal veya ametal elementlerle farklı özellikler gösteren bileşikler oluşturmaktadır. Bu sayede, birçok bor bileşiği, endüstrinin farklı dallarında kullanılmaktadır. Bor, bileşiklerinde metal dışı bileşikler gibi davranır. Saf bor ise karbon gibi elektrik iletkeni özelliği taşımaktadır. Kristalize bor, görünüm ve optik özellikleri açısından elmasa benzer ve neredeyse elmas kadar serttir. Bor'un saf elementi; ilk kez 1808 yılında Fransız kimyager J.L. Gay - Lussac ve Baron L.J. Thenard ile İngiliz kimyager H. Davy tarafından elde edilmiştir (ETİ MADEN,06.04.2021.19:30).

Elmastan sonra ametaller arasında elektropozitifliği en yüksek olan Bor, yanıcı fakat tutuşma sıcaklığının yüksek olmasından dolayı, yanma sonucunda kolaylıkla aktarılabilecek kan ürün vermesi ve çevreyi kirletecek emisyon açığa çıkarmaması gibi bir özelliğe sahip olduğundan kan yakıt hücresi olarak da kullanılmaktadır (Bilgiç vd.,2013).

Tablo 1: Bor elementinin fiziksel özellikleri

\begin{tabular}{|c|c|}
\hline Özellik & Değeri \\
\hline Atom Ağırlığı & $10,811+(-) 0,005$ veya 0,007 \\
\hline Ergime Noktası & $2190+20 \mathrm{~T}$ \\
\hline Kaynama Noktası & $3660 \mathrm{C}$ \\
\hline Isıl Genleşme Katsayısı(25-1050Carası re) & $5 \times 106-7 \times 106$ \\
\hline Knoop Sertliği & $2100-2580 \mathrm{HK}$ \\
\hline Mohs Sertliği (elmas-15) & 11 \\
\hline Vickers Sertliği & $5000 \mathrm{HV}$ \\
\hline
\end{tabular}

Yeryüzünün 51. yaygın elementi olan bor, yeryüzünde toprak, kayalar ve suda yaygın olarak bulunan bir elementtir. Yüksek konsantrasyonda ve ekonomik boyutlardaki bor yatakları, borun oksijenle bağlanmış bileşikleri olarak daha çok Türkiye ve Amerika Birleşik Devletleri'nin kurak volkanik ve hidrotermal aktivitesinin yüksek olduğu bölgelerde bulunmaktadır. Yukarıda, Şekil 1'de bor elementinin fiziksel özellikleri yer almaktadır (Bilgiç, M., Dayık, M. Teknolojik Araştırmalar: TTED 2013 (2) 27-37 29 2.2.)

Periyodik tabloda B simgesi ile gösterilen borun atom numarası 5, atom ağırlığ 1 ise 10,81'dir. Yarı metal ve yarı iletken özelliğe sahip olan bor elementi periyodik cetvelin 3A grubunda yer almaktadır. Bor, element olarak doğada B10 ve B11 olarak adlandırılan iki ayrı kararlı izotoptan oluşmaktadır. B10 izotopunun doğada bulunma oranı \%19,1-20,3, B11'in ise \%79,780,9 ' dur. Bor yüksek sıcaklıkta su ile reaksiyona girerek borik asit ve diğer ürünleri oluşturur. Bor mineralleri yapılarında farklı oranlarda bor oksit içeren doğal bileşiklerdir (ETİ MADEN,06.04.2021.19:00). 


\subsection{Borun Kullanım Alanları}

Doğada 230' dan farklı bor minerali bulunmaktadır. Ticari öneme sahip başlıca bor mineralleri ise;Kernit,Tinkalkonit,Tinkal.Probertit,Üleksit. Kolemanit, Meyerhofferit. İnyoit, Pandermit, İnderit. Hidroborasit, Borasit, Aşarit, Datolit, Sasssolit (doğal borik asit) 'tir (ETIMADEN,06.04.2021.19:00).

Ülkemizde Eti Maden tarafından yüksek katma değerli ürünlere dönüştürülen başlıca bor mineralleri ise; Tinkal, Kolemanit ve Üleksit'tir. Tinkal; Eskişehir - Kırka yatağında bulunmaktadır. Renksiz ve saydam olmasına rağmen, bileşimindeki çeşitli safsızlıklar nedeniyle pembe, sarımsı, gri renklerde bulunmaktadır. Tinkal, öncelikli olarak cam sanayi ve tarım alanlarında kullanılmaktadır. Kolemanit; Türkiye' de Bor bileşikleri içinde en yaygın olarak bulunabilen kolemanit (özellikle Emet, Bigadiç ve Kestelek yataklarında) , killer içinde cevher boşluklarında, iri, parlak, saydam kristaller olarak bulunmaktadır.

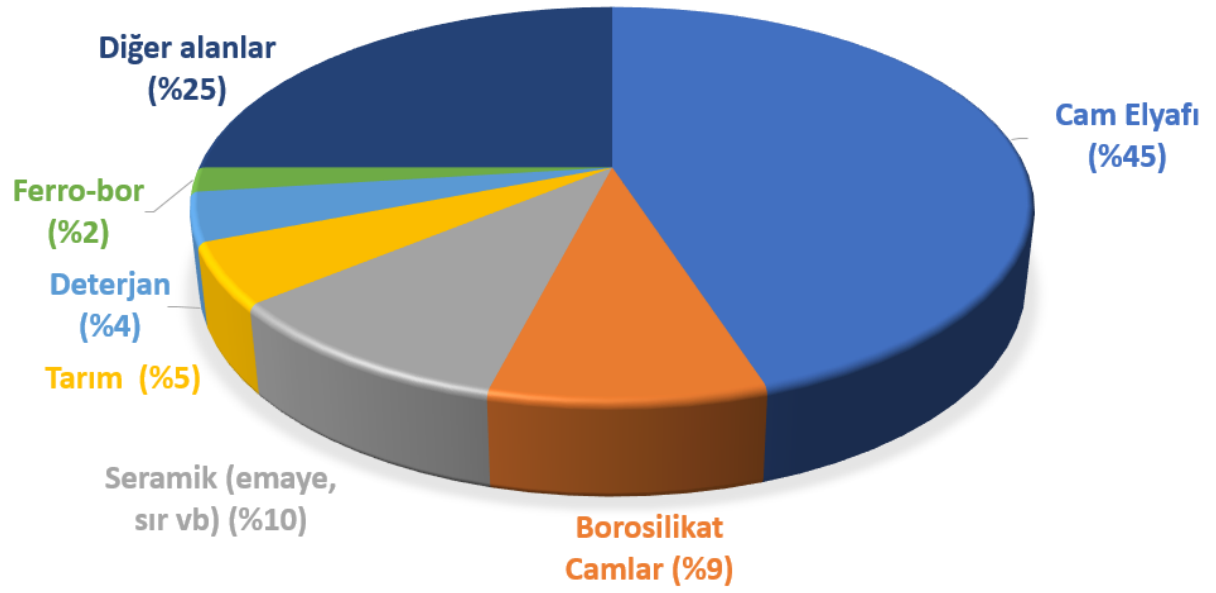

Şekil 1: Borun başlıca kullanım alanları ve sıklığı (Helvacı, 2015)

Mineral bakımından oldukça zengin olan Kolemanit, sanayide başlıca; Metalürji, cam elyafı, gübre, deterjan ve kozmetik sektörlerinde de sıklıkla tercih edilmektedir. Üleksit; Emet, Kırka ve Bigadiç bor yataklarında yaygın olarak bulunan Üleksit minerali, birçok sektörde yaygın olarak kullanılmaktadır. Üleksit doğada saf haliyle; masif, karnabahar, lifsel, koni, rozet, pamuk yumağı ve çubuk görünümüyle yer almaktadır.

Yine mineral bakımından oldukça zengin bir bor çeşidi olarak, kaliteli, sürdürülebilir ve inovatif ürünlere dönüştürülebilme potansiyeli ile en önemli bor bileşiklerindendir. Üleksitin sanayide başlıca kullanım alanları ise; 1Sı ve ses yalıtımı, cam, seramik ve gübre endüstrisi, borik asit ve boraks üretimidir.

Cam elyafı, borosilikat camlar (borcam), deterjan, emaye, tarımda suni gübre, ilaç sanayi, nükleer reaktörlerde koruma malzemesi, havacılık için kompozitler, fotoğrafçılık kimyasalları, rüzgâr tribünlerinde kullanılan güçlü mıknatıslar gibi geniş bir yelpazeye yayılan çok farklı sanayi ürününde bor elementi kullanılmaktadır.

Borun diğer sektörlerdeki kullanım alanları ise; Temizleme ve beyazlatma sanayinde, Metalürji alanlarında, Havacılık ve Uzay araştırmalarında, Elektrik ve Elektronik sektöründe, Bilgisayar Sektöründe, İletişim alanlarında, Otomobil sektöründe, Enerji alanlarında, Sağlık 
alanında, İlaç sektöründe ve Kozmetik sanayinde, Tekstil alanlarında, Kimya sanayinde, Tıp dallarında, Kağıt sanayinde, Tarımsal sektörde, Askeriye ve zırhlı araçlarda, Cam sanayinde, Seramik sektöründe, Plastik sektöründe, Çimento ve inşaat alanlarında, Nükleer sanayinde, Fotoğrafçllıkta, Boya sanayinde, Mumyalama alanında, Kauçuk sektöründe, İleri teknolojik araştırma sektöründe, Fiber optiklemede, Patlayıcı maddelerde, Manyetik cihazlarda kullanımı şeklinde sıralanabilir.

\section{TÜRKIYYEDE VE DÜNYADA BOR}

\subsection{Türkiyede Bor}

Dünya bor rezervlerinin \%73'üne sahip olan Türkiye' de bilinen bor yatakları; Eskişehir - Kırka, Kütahya- Emet, Balıkesir Bigadiç, Bursa-Kestelek'te bulunmaktadır. Türkiye'de rezerv açısından en çok bulunan bor mineralleri Tinkal ve Kolemanit'tir. Türkiye'de Tinkal yatakları Eskişehir - Kırka' da, kolemanit yatakları ise Kütahya - Emet, Balıkesir - Bigadiç ve Bursa - Kestelek'te bulunmaktadır. Ayrıca, Balıkesir - Bigadiç'te üleksit rezervi mevcut olup Bursa - Kestelek'te zaman zaman Üleksit yan ürün olarak elde edilmektedir.

2840 sayılı Kanun ile birlikte Türkiye'de bor ve bor ürünlerinin üretilmesi, işletilmesi ve pazarlanması faaliyetlerini gerçekleştirme görevi Eti Maden tarafından yürütülmektedir. Eti Maden bünyesinde bulunan 4 İşletme Müdürlüğündeki tesislerde ağırlıklı olarak Boraks Pentahidrat, Boraks Dekahidrat, Borik Asit, Etidot-67, Bor Oksit, Çinko Borat, Kalsine Tinkal, Susuz Boraks, Ögütülmüş Kolemanit ve Ögütülmüş Üleksit üretilerek yurt içi ve yurt dişı pazarlara sunulmaktadır. Eti Maden'in 2017 yllında toplam rafine bor üretim kapasitesi yaklaşık 2,7 milyon tondur.

Bor ürünleri Türkiye'de; \%36 cam, \%31 seramik, \%9 temizlik- deterjan, \%7 tarım, \%4 tutkal ve \%14 pay ile diğer alanlarda kullanılmaktadır. Eti Maden, yurt içi bor taleplerinin tamamını karşılamaktadır. Türkiye ekonomisinin uluslararası alanda prestijli bir konuma erişmesine yardımcı olan Eti Maden, 2016 yılında Türkiye'nin En Büyük 1000 İhracatçı Firma sıralamasında 15'inci en çok ülkeye ihracat yapan firma sıralamasında ise 90 firma arasında 14 'üncü sırada yer almaktadır.

\subsection{Dünyada Bor}

Velioğlu vd. (1999) göre, dünya bor rezervinin \%73'üne sahip olan ülkemizi, sırasıyla ABD, Arjantin, Peru, Rusya ve Çin izlemektedir. Fakat, üretim açısından ülkemiz, Bor üreten altı ülke içerisinde $A B D$ 'den sonra ikinci sırada yer almaktadır. Bor üretiminin hemen hemen tamamına yakın kısmını işledikten sonra ihraç etmektedir. 


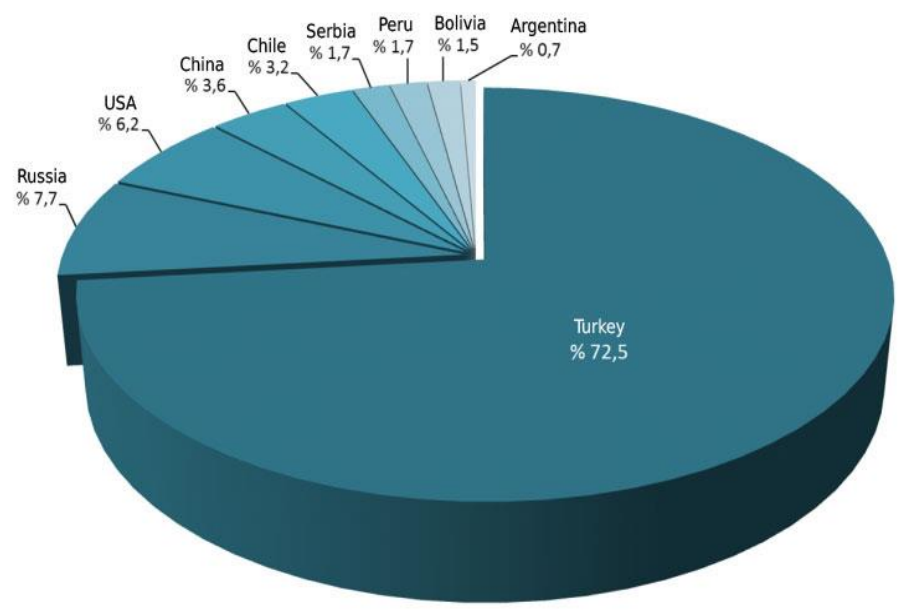

Şekil 2: Dünya Bor Rezervi

Dünya bor ürünleri tüketimi ise 2000 yılında 3,1 milyon ton iken, bu değer 2014 yılında 4,3 milyon ton, 2015 yılında 3,8 milyon ton, 2016 yılında 3,77 milyon ton, 2017 y1lında 3,87 milyon ton olarak gerçekleşmiştir. Dünyada sektörel bazda bor ürünlerinin tüketimi: \%47 cam sektörü, \%16 tarım-gübre, \%15 seramik sektörü, \%2 temizlik ve deterjan sektörleri ve \%20 diğer sektörlerdir.

\section{BOR KATKILI NANOKOMPOZIT MALZEMENIN \% 100 PAMUKLU KUMAŞA UYGULANMASI}

Hızlı üretim ve tüketimin yaşandığı çağımızda, Tekstil endüstrisinin de dahil olduğu çok çeşitli endüstri alanlarında kullanılan birçok sentetik, geri dönüşümü olmayan malzeme ve katkı elemanları, kirlenmeye neden olarak ekosistemimize zarar vermektedir. Tekstil alanında bazı teknik özelliklerinden dolayı sıklıkla tercih edilen sentetik giysiler, zaman içinde doğaya karışarak başta sularımız vasıtası ile insanlar dahil birçok canlının, besin zincirine mikro plastikler olarak girerek, ciddi sağlık sorunlarına neden olmaktadır.

Ekosistemimiz ve içinde yaşayan tüm canlılar, hatta bitkiler için büyük bir tehlike oluşturan bu kirlenmeye karşı, dünyada çeşitli önlemler alınmaya çalışılsa da yeterli düzeyde değildir. Özellikle Tekstil endüstrisi halen kalıcı ve sürdürebilir önlemler almaktan çok uzaktır.

Geleceğin en stratejik cevheri olarak görülen ve bu değerli madenin dünyada 3/2'sine sahip olan ülkemizde bor madeninin belli başlı endüstri kolları dışında halen çok da sisteme sokulmaması ve ülke ihracatında ciddi bir payı olan çokça tekstil ürünlerinin üretildiği bu alanda yeteri kadar çalışma yapılıp tanınmadığı ya da çalışmaların son derece kısıtlı olduğu yapılan literatür çalışmalarından da görülmüştür.

Hem ekosistemimize sağlayabileceği olağan katkılar, hem milli hazinemiz olarak görülen bor madeninin kullanım alanlarının genişletilmesinin ülkemize sağlayacağı ekonomik girdiler hem de doğada yaşayan tüm canlıların sağlı̆̆ olarak adının endüstride ve akademik çalışmalarda daha sık geçmesi gerekmektedir.

Bu düşünceden hareketle, bor katkılı Nanokompozit malzeme \%100 pamuk elyafına bir dizi laboratuvar testleri ile işlenmiş ve elde edilen bulgular makale çalışması olarak derlenmiştir. Çalışma kapsamında Anti-Bakteriyel ve Anti-Viral testler uluslararası akredite laboratuvarına gönderilerek teyit alınmıştır. 
Çalışmada Nanokompozit kullanılmasının nedeni ise; Nanokompozitlerin; modülü arttırması, güçlendirmesi, 1sı direncini arttırması, malzemeye gaz sızmasını engellemesi ve yanıcılı̆̆ı azaltılması gibi özellikleridir. Laboratuvar ortamında oluşturulan Bor Katkılı Nanokompozit Malzemenin \% 100 Pamuklu Kumaşa Uygulanmasıyla oluşturulan çalışmada; pamuğun elyaf yapısına derinlemesine uygulandığı ön işlemde, pamuklu ürün ağır metallerden arındırılmıştır.

\section{BULGULAR}

İşlem sonrasında yapılan atık su analizinde pamuklu üründe hiçbir ağır metal kalıntısına rastlanmadığı gibi, atık suyun $\mathrm{PH}$ seviyesi içilebilir seviye olan 8.00 olarak ölçülmüştür. Bununla birlikte pamuklu ürünün aşağıda belirtilen özellikler kazandığg görülmüştür;

1. Anti - Bakteriyel

2. UPF 50+ Ultraviole Koruma

3. Elektromanyetik Kalkanlama

4. Radon Gazı Absorbsiyonu

5. Geç Tutuşurluk

6. Artırılmış Mukavemet

7. Üstün Su Emicilik- Hidrofilite

8. Non-Formaldehit

\subsection{Anti- Bakteriyel}

Bor Katkılı Nanokompozit Malzemenin \% 100 Pamuklu Kumaşa Uygulanması işleminde, pamuk elyafı üzerinde yaptığı en önemli değişimin, kalıcı Anti-Bakteriyel özellik sağlaması olduğu görülmüştür. Bilindiği üzere, bakteriler gerek tekstil ürünlerini kullanımımız sürecinde, gerek kendi ten ve terimizden, gerekse çevresel faktörlerden dolayı ortaya çıkarak yaşam kalitemizi birçok alanda tehdit eder. Örneğin; Escherichia Coli (Bağırsaklarda yaşar ve ciddi ishale neden olur), Fecal Bacteria (Tifo ve muhtelif enfeksiyonlara neden olur), Rhinovirus (Soğuk algınlığına sebep olur), Norovirus (Erişkin ve çocuklarda ishale neden olmaktadır) , Candida Albicans (Özellikle genital bölgede sağlığı tehdit eden bir mantar türü), Klebsiella Pneumoniae (Akciğer yıkımına neden olabilir), Staphylococcus Aureus (Cilt enfeksiyonlarına neden olur)

Bununla birlikte bakterilerin neden olduğu, terleme sonrası oluşan kötü kokular, ortam neminden dolayı oluşan küfler, yeterince temizlenemeyen tekstil ürünleri, sağlı̆̆ımızı ve konforumuzu her alanda tehdit etmektedir.

Bor Katkılı Nanokompozit Malzemenin \% 100 Pamuklu Kumaşa Uygulanması işleminde yapılan analizler sonucu, işlemin, \%86 kadar varan oranda anti-bakteriyel etkiye sahip olduğu ve doğal mineral yapısından dolayı da Anti-Alerjik ve Anti-Fungal olduğu için kötü koku üretmediği görülmüştür. Buna göre, kullanım alanları: Hijyen gerektiren, nem ve ısının yüksek olduğu, Hastane, Spa, Otel, gibi alanlar, Bebek ürünleri, İç çamaşırı, Spor tekstilleri, Plaj havluları ve benzeri alanlarda kullanılmasının uygun olduğu düşünülmektedir. 


\subsection{UPF 50+ Ultraviole Koruma}

Günümüzde yapılan birçok bilimsel çalışma sonucu, direk güneş ışınlarına maruz kalan derinin erken yaşlandığı ve ileri safhalarda da kanserojen etkisinden dolayı kanser riskini artırdığı bilinmektedir. Bor Katkılı Nanokompozit Malzemenin \% 100 Pamuklu Kumaşa Uygulanması işleminin güneşten gelen zararlı ışınları kalkanlama özelliğine sahip olduğu, çalışma kapsamında uluslararası akredite laboratuvarında yapılan testlerde UPF (Ultraviolett Protection Factor) 50+ sonucu ile \%99' a yakın koruma sağladığı görülmüştür.

$\mathrm{Bu}$ sonuç bilindiği kadarı ile bu alanda \%100 pamuklu bir üründe elde edilen en iyi sonuçlardan biri olmuştur. Buna göre, kullanım alanları; Dış mekan tekstili, bebek ve çocuk giysileri, sağlık açısından güneşten korunması gereken UV hassasiyeti olan yetişkinler, doğa ve açık hava sporcuları, askeri üniformalar olarak sıralanabilir.

\subsection{Elektromanyetik Kalkanlama}

Radyasyon, foton ve partiküller halinde doğada bulunan ve bizimle yaşayan bir enerji paketidir. Gelişen teknoloji ile birlikte iletişimimizi sağlayan radyo dalgalarında, evimizde, cebimizde, iş yerimizde, hastanede, kısacası yaşamımızın her alanında radyasyona maruz kalmaktayız. Bilinen sayısız tehlikelerinin yanı sıra, Dünya Sağlık Örgütü raporuna göre, elektromanyetik dalgalar temelde sinir sistemimizi etkileyerek, anksiyete, baş ağrısı, vücut ısısında artma, yorgunluk, uyku bozukluğu, depresyon ve cinsel istekte düşüşe de neden olabilmektedir. Özellikle hamile kadınların radyoaktif alanlardan korunması, ileride çocuklarının lösemi başta olmak üzere birçok sağlık sorunlarına yakalanma riski açısından önem arz etmektedir.

Bor Katkılı Nanokompozit Malzemenin \% 100 Pamuklu Kumaşa Uygulanması ile işlem gören pamuklu kumaşların , \%20 ya varan oranda nötron tutma kapasitesine sahip olduğu ve bu sayede radyasyon absorblama özelliği taşıdığı gözlemlenmiştir. Buna göre, kullanım alanları; Anti-Stres, koruyucu giysi kategorisinde, hamile kıyafetleri, bebek kıyafetleri, hastane personeli, radyoaktif alanlarda çalışanlar, pilot ve kabin görevlileri, askeri radar personeli, sürekli bilgisayar başında çalışanlar olarak sıralanabilir.

\subsection{Radon Gazı Absorbsiyonu}

Radon gazı, genellikle ev, işyeri gibi kapalı mekanlarda bulunan ve doğada bulunan radyoaktif bir gazdır. Dünya Sağlık Örgütüne göre Radon gazı, sigaradan sonra akciğer kanserine neden olan ikinci etkendir. Sigara içme oranına ve ülkenin ortalama Radon gazı oranına göre akciğer kanserine etkisi \%3-14 arasında yer almaktadır. Sigara içenlerin Radon gazından etkilenme oranı normale göre yaklaşık 25 kat daha fazla olduğu bilinmektedir.

Bor Katkılı Nanokompozit Malzemenin \% 100 Pamuklu Kumaşa Uygulanması ile işlem gören pamuklu kumaşların \%22 ye varan oranla Radon gazını tuttuğu ölçülmüştür. Buna göre, kullanım alanları; İç çamaşırı, pijama, ev giysileri, çarşaf, nevresim, havlu, bornoz, döşemelik kumaşlar ve benzeri ürünlerdir.

\subsection{Geç Tutuşurluk}

Çalışma kapsamında yapılan laboratuvar testlerinde, Bor Katkılı Nanokompozit Malzemenin \% 100 Pamuklu Kumaşa Uygulanması ile işlem gören pamuklu kumaşların \%30 oranında geç tutuşurluğa sahip olduğu ölçülmüştür. Yapılan literatür araştırmalarında, tekstillerin 
herhangi bir yangın tehlikesinde ilk tutuşanlar arasında \%24 gibi tehlikeli bir oranda olduğu tespit edilmiştir. Geç tutuşurluk kamusal alanlardan evlerimize kadar hayatımızın tüm alanlarında büyük öneme sahiptir. Buna göre, kullanım alanları; perde, çarşaf, havlu, bornoz, koruyucu giysiler, iş kıyafetleri (itfaiye, askeri giysiler vb.), mutfak giysileri

\subsection{Artırılmış Mukavemet}

Otel ve hastane tekstilleri gibi yoğun yıkama ve kimyasallardan dolayı ürünler çok hızlı bir şekilde yıpranmaktadır. Özellikle zor şartlarda kullanılan ve gerilmelerin yoğun olduğu tekstil ürünlerinde, endüstriyel yıkama şartlarından dolayı da çabuk yıpranan ve yırtılan tekstil ürünlerinde standart olarak kabul edilen mukavemet ölçüsü 250 (N) 'dir. Bor Katkılı Nanokompozit Malzemenin \%100 Pamuklu Kumaşa Uygulanması ile işlem gören pamuklu kumaşlarda ise bu oranın 968 (N) olarak, kabul gören normal standartların 3 katından fazla mukavemete sahip olduğu görülmüştür. Bu sonuç literatür araştırmalarından da bilindiği kadarı ile \%100 pamuklu bir üründe, herhangi bir karışım eklenmeden sağlanabilecek en üstün değerlerden biridir. Böylelikle tekstillerin ömürleri boyunca karşılaşabilecekleri en önemli sorunlardan birinin ortadan kalkmasına olanak sağlarken, tasarrufa da imkân sağlayarak ekonomiye katkı sağlayacağı aşikardır. Buna göre, kullanım alanları; otel, spa, hastane tekstilleri (havlu, bornoz, nevresim), günlük giysiler, askeri ve koruyucu giysiler olarak siralanabilir.

\section{7. Üstün Su Emicilik- Hidrofilite}

Bor Katkılı Nanokompozit Malzemenin \% 100 Pamuklu Kumaşa Uygulanması işlemi ile kumaşın doğal yüzeyi bozulmadan sağlanan homojen yüzey ile üstün bir hidrofilite (malzemenin suyu emme özelliği-su severlik) sağlandığı görülmüştür. Şöyle ki; pamuklu ürünlerde standart olarak kabul edilen 5-10 sn arasındaki su emilimi, çalışmada 1 sn'nin altına inmiş, sıvı yayılımın yüksek olmasına bağlı olarak da hızlı kuruma özelliği kazanmıştır. Buna paralel olarak önemli ölçüde sıvı ve nem kontrolü de sağlanmıştır. Buna göre, kullanım alanları; Havlu, Bornoz, Kurulayıcılar, Spor giysileri, İç çamaşırları ve insan vücudundaki çok terleyen ve nemli yerler.

\subsection{Non-Formaldehit}

Tekstil ürünlerine bazı özellikler kazandırılmak amacıyla formaldehit uygulanır. Formaldehit bebek ürünlerinde 16 ppm'e kadar ve yetişkinlerde 75 ppm e normal kadar kabul edilmesine rağmen alerjik reaksiyonlara sebebiyet vermekle birlikte aynı zamanda da kanserojendir.

Bu nedenle Bor Katkılı Nanokompozit Malzemenin \% 100 Pamuklu Kumaşa Uygulanması işleminde formaldehit kullanılmamıştır. Buna göre, kullanım alanları; Bebek ve yetişkin iç giyim, tene temas eden tüm tekstil ürünleri (Gömlek ve T-Shirt, çorap, spor giysileri, havlu, bornoz, nevresim), Üniformalar: (Otel, Spa, Restoran, Kafe, hastane personeli, hasta kıyafetleri, güvenlik personeli, askeriye).

\section{SONUÇ}

Yapılan literatür taramalarından da görüleceği üzere ülkemiz ve gelecekte petrol kadar önemli olabileceği düşünülen bor madeninin dünyadaki en büyük rezervine sahip olmasına rağmen dünya pazarındaki payımız yetersizdir. Bor rezervi miktarı ve kalitesi açısından çok avantajlı 
olan ülkemizin halen boru işlenmemiş ve ham olarak ihraç etmesi bor piyasasındaki karını neredeyse yarı yarıya düşürmektedir.

Tez çalışmasında, örnek bir araştırma ve uygulama üzerinden, ülkemizin en önemli doğal hazinelerinden biri olan, bor madeninin doğal özelliklerinin, hem akademik hem de sektörel bazda tekstil ve moda tasarımında uygulama alanlarının genişletilmesi amaç alınmış, dünyada sayılı bor rezervlerinden birine sahip olan ülkemizde bor madeninin interdisipliner bir araştırma ve çalışma ile kullanım olanaklarının ekonomiye sağlayacağı imkanlar da değerlendirilmiştir. Konu ile ilgili yapılan literatür çalışmalarında, Tekstil ve Moda tasarımında ARGE alanında yenilikçi ürünlerin ortaya çıkarılması hem akademik anlamda

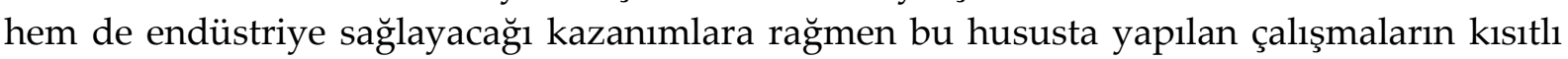
olduğu görülmüştür.

Ülkemizde bor madeninin belli başlı endüstri kollarında birbirini ikame eder şekilde değerlendirilmesi, ürün çeşitliliğin artırılmaması ve bazı endüstri kollarında henüz değerlendirilmemesi ya da çok kısıtlı kalması şüphesiz, gerek üniversite gerek sanayi gerekse üniversite-sanayi birlikteliğiyle yapılması gerekli ar-ge çalışmalarının eksikliğine bağlıdır. Dünyada bor rezervi açısından bu kadar önemli bir role sahipken ülkemizin bor ile ilgili yapılan en az akademik yayına sahip ülkelerden biri olması da bu durumu destekler niteliktedir. Ülkemiz ham bor ihraç etme olumsuzluğundan uzaklaşarak yüksek katma değeri olan işlenmiş bor ihraç etmeye yönelik projeleri hayata geçirmelidir. Ülkemizde Bor Araştırma ve Ürün geliştirme merkezleri açılmalı ve birçok endüstri alanı üretiminde bor madenini kullanımına önem verilmelidir. Özellikle yine dünya pazarında ürün üretiminde ve ihracatında önemli bir paya sahip olduğumuz tekstil sanayinde, bor rezervimiz ve tekstil ihracatındaki avantajlarımız göz önüne alındığında bor ile ilgili farkındalık seviyemizi artırarak dolaşıma sokmamız ekonomik olarak ülkemize sayısız katkılar sağlayacaktır.

Nanokompozit malzemenin çeşitli teknik ve kimyasal işlemlerle \%100 pamuklu ürüne tatbik edilmesiyle; Anti-Bakteriyel, UPF 50+ Ultraviole Koruma, Elektromanyetik Kalkanlama, Radon Gazı Absorbsiyonu, Geç Tutuşurluk, Artırılmış Mukavemet, Üstün Su EmicilikHidrofilite, Non-Formaldehit gibi birçok teknik özellik kazanan bor katkılı yeni pamuklu kumaşlar aşağıdaki görsellerde yer alan çeşitli tekstil ürünlerine dönüştürülmüştür. Çalışmada bor katkılı pamuklu üründen yapılan ürün tasarımlarının bir örnek teşkil etmesi ve yeni çalışmalara ışık tutması ümit edilmektedir.

\section{UYGULAMALAR}

Araştırmanın bu bölümünde İsa Dal tarafından ortaya konulan "Bor Katkılı Nanokompozit Malzemenin \% 100 Pamuklu Kumaşa Entegresi İle Tasarım ve Ürüne Dönüştürme" konulu teknolojik tekstil tasarımı çalışmaları yer almaktadır (Bakınız Şekil 3-13). 


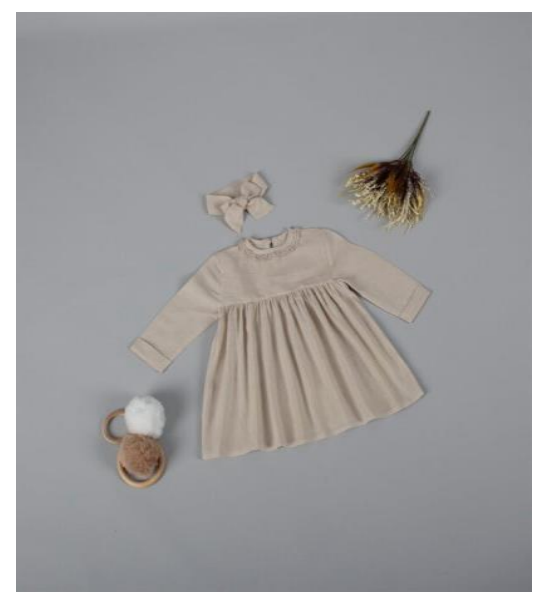

Şekil 3: Bor Katkılı Nanokompozit Malzemenin \% 100 Pamuklu Kumaşa Entegresi, Bebek Giysisi

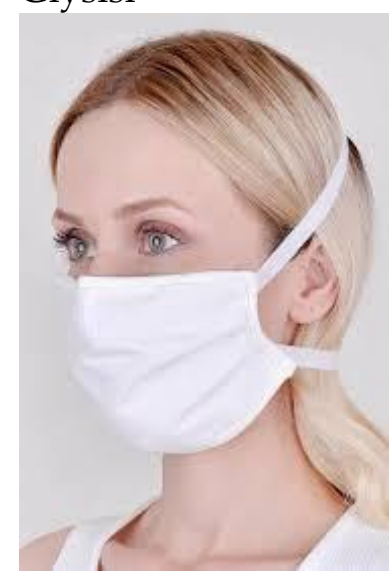

Şekil 4: Bor Katkılı Nanokompozit Malzemenin \% 100 Pamuklu Kumaşa Entegresi, AntiBakteriyel Maske

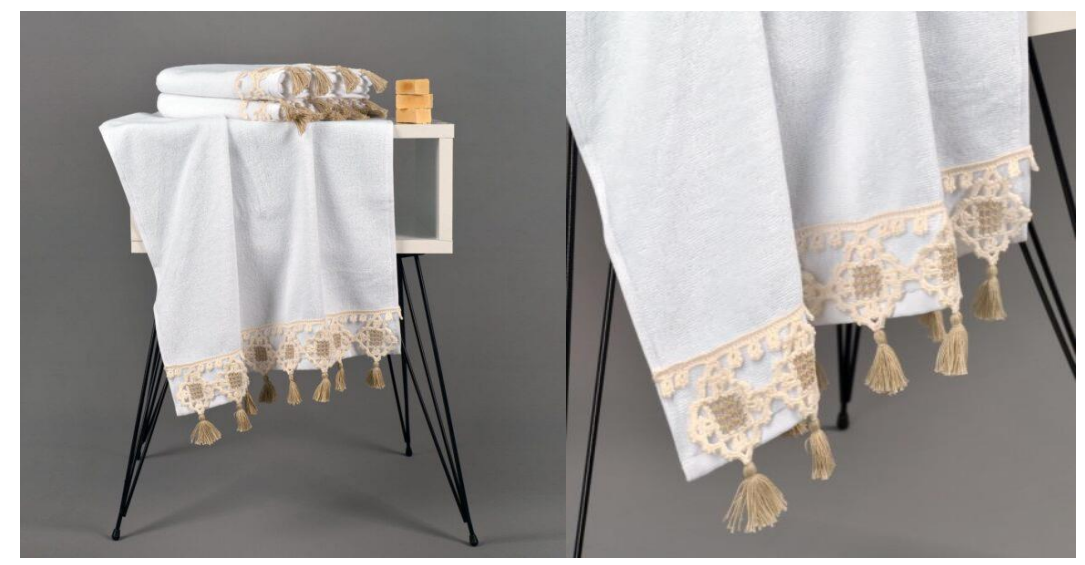

Şekil 5 ve 6: Bor Katkılı Nanokompozit Malzemenin \% 100 Pamuklu Kumaşa Entegresi, El Havlusu 


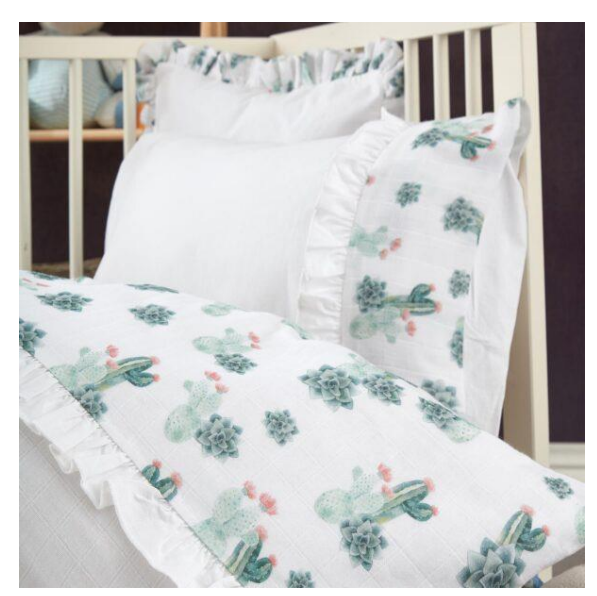

Şekil 7: Bebek Uyku Seti

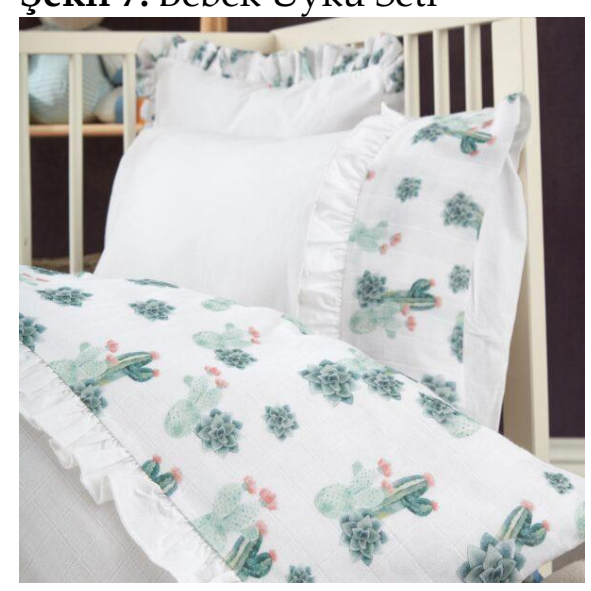

Şekil 8: Bebek Yorgan ve Yastık Takımı

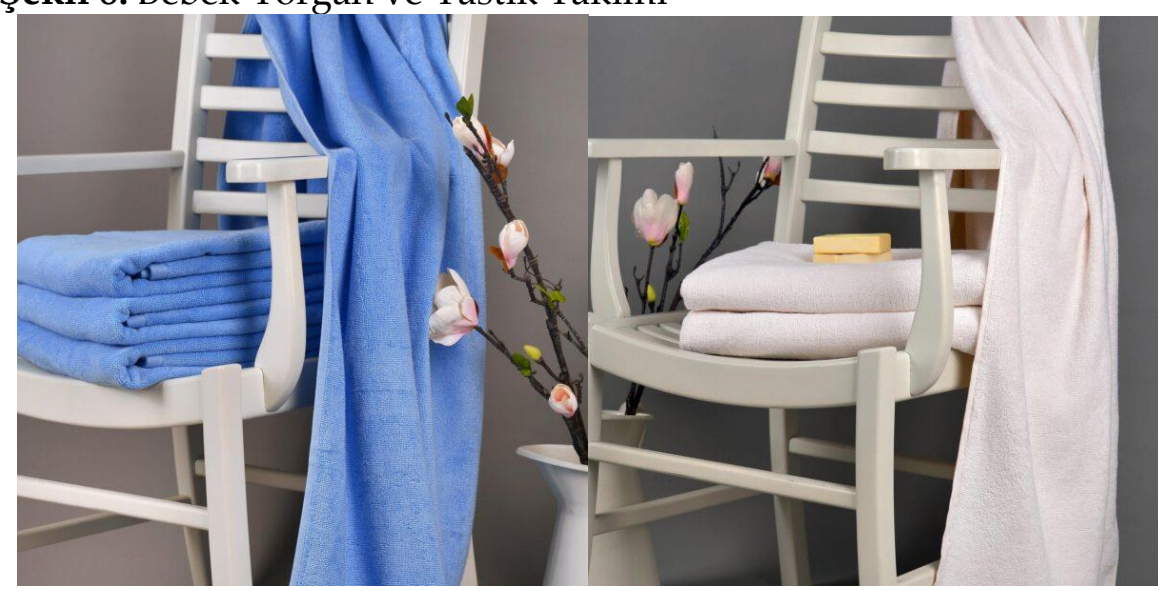

Şekil 9 ve 10: Bor Katkılı Nanokompozit Malzemenin \% 100 Pamuklu Kumaşa Entegresi, Banyo Havlusu 


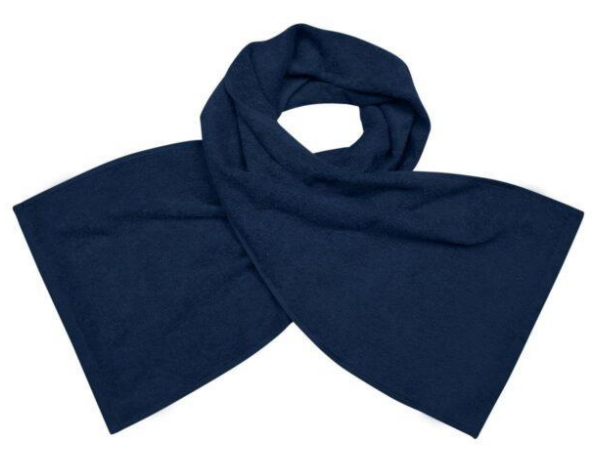

Şekil 11: Bor Katkılı Nanokompozit Malzemenin \% 100 Pamuklu Kumaşa Entegresi, AntiBakteriyel Spor Havlusu

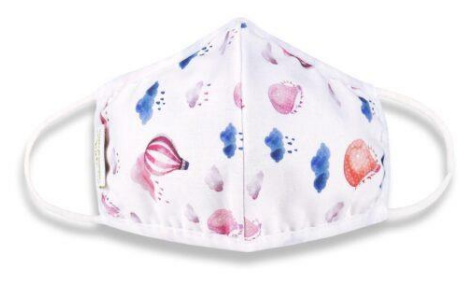

Şekil 12: Bor Katkılı Nanokompozit Malzemenin \% 100 Pamuklu Kumaşa Entegresi, AntiViral ve Anti Bakteriyel 0-4 yaş Bebek Maske

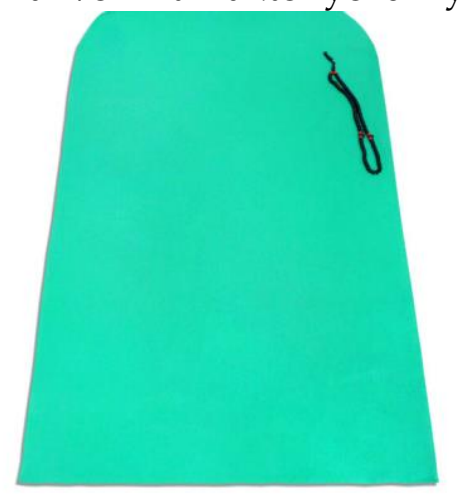

Şekil 13: Bor Katkılı Nanokompozit Malzemenin \% 100 Pamuklu Kumaşa Entegresi, AntiViral ve Anti- Bakteriyel Seccade

\section{Araştırmacıların Katkı Oranı Beyanı / Researchers' Contribution Rate Statement} Çalışmaya İsa DAL \% 75, Şöhret Aktepe DAL \%25 oranında katkı sağladığını beyan etmiştir.

Araştırmacıların Çatışma Beyanı / Researchers'Conflict of Interest Statement

Yazarlar, bu çalışmada potansiyel bir çıkar çatışması olmadığını beyan etmişlerdir. 
The authors declare that there is no potential conflict of interest in this study.

\section{KAYNAKÇA}

Aftalion, F. (1991). A History of the International Chemical Industry. Philadelphia: University of Pennsylvania Pres.

Barger, H. \& Schurr S. H. (1944). The Mining Industries, 1899-1939: A Study of Output, Employment, and Productivity. , New York: National Bureau of Economic Research.

Bayar D. (2001). Sulu Çözeltilerden Absorpsiyonla Bor Giderimi ve Deney Tasarımı. Eskişehir: Eskişehir Osmangazi Üniversitesi Fen Bilimleri Enstitüsü.

Bilgiç, M. \& Dayık, M. (2013). Borun özellikleri ve tekstil endüstrisinde kullanımı. Tekstil Teknolojileri Elektronik Dergisi, 7(2) 27-37.

Boren (a), http://www.boren.gov.tr/tr/projeler/proje-ciktilari/proje-istatistikleri, (10.04.2018).

Buluttekin, M.B. (20-22 Şubat 2008). “Bor maden ekonomisi: Türkye'nin dünya bor piyasasındaki yeri", 2. Ulusal İktisat Kongresi, İzmir.

Choi, S. R., Bansal N. P. \& Garg, A. (2007). Mechanical and microstructural characterization of boron nitride nanotubes-reinforced sofc seal glass composite. Materials Science and Engineering, Volume 460-461, 509-515.

Dırak, S. (2011). Eti Maden Müdürlügü Kırka Bor İşletmesi Bor Endüstri Atıklarında Eser Elementlerin Tayini ve Lityumun Kazanılması, Kütahya: Dumlupınar Üniversitesi Fen Bilimleri Enstitüsü.

Ersoy, Y. \& Helvac1, C. (2007). Stratigraphy and geochemical features of the early miocene bimodal (ultrapotassic and calc-alkaline) volcanic activity within the netrending Selendi Basin, Western Anatolia, Turkey, Turkish Journal of Earth Sciences, 16 (2), 117 139.

Eti Maden İşletmeleri Genel Müdürlüğü, (2016). Strateji Geliştirme Başkanlığı Bor Sektör Raporu, 5-15.

Helvacı, C. (2015). Bor yataklarının genel değerlendirilmesi ve gelecek öngörüsü günümüz teknolojilerinde bor ürünleri. Madencilik ve Yer Bilimleri Dergisi, 47.

Hildebrand, G. H. (1982). Borax Pioneer: Francis Marion Smith. San Diego-California: HowellNorth Books.

Karagölge, Z., Ceyhun, İ. \& Alkan, M. (2002). Yüzyılın petrolü bor. Standart, Eylül 2002, 4551.

Kılınç, E., Mordoğan, H. \& Tanrıverdi, M. (2001). Bor Minerallerinin Önemi, Potansiyeli, Üretimi ve Ekonomisi. Dokuz Eylül Üniversitesi Hammaddeler Sempozyumu.

Telli, Ö.F.G. (2008). Bor Uç Ürünleri ve Üretim Yöntemleri. İzmir: Dokuz Eylül Üniversitesi Fen Bilimleri Enstitüsü, Yayımlanmamış Yüksek Lisans Tezi.

TESAM. http://tesam.org.tr/bor-raporu/. (02.03.2018). 
TMMOB, 2016,Bor Raporu, Ankara: Türk Mühendis ve Mimar Odaları Birliği, 62.

Yenmez, N. (2009), Stratejik Bir maden olarak bor minerallerin Türkiye için önemi, Coğrafya Dergisi, 19, 59-94. 